\title{
Teachers' Beliefs of Learner Autonomy in Secondary Schools
}

\section{Siti Nur Yusof}

To Link this Article: http://dx.doi.org/10.6007/IJARBSS/v11-i2/9196

DOI:10.6007/IJARBSS/v11-i2/9196

Received: 14 December 2020, Revised: 17 January 2021, Accepted: 31 January 2021

Published Online: 20 February 2021

In-Text Citation: (Yusof, 2021)

To Cite this Article: Yusof, S. N. (2021). Teachers' Beliefs of Learner Autonomy in Secondary Schools. International Journal of Academic Research in Business and Social Sciences, 11(2), 1006-1012.

Copyright: (c) 2021 The Author(s)

Published by Human Resource Management Academic Research Society (www.hrmars.com)

This article is published under the Creative Commons Attribution (CC BY 4.0) license. Anyone may reproduce, distribute, translate and create derivative works of this article (for both commercial and non-commercial purposes), subject to full attribution to the original publication and authors. The full terms of this license may be seen

at: http://creativecommons.org/licences/by/4.0/legalcode

\section{Vol. 11, No. 2, 2021, Pg. 1006 - 1012}

Full Terms \& Conditions of access and use can be found at http://hrmars.com/index.php/pages/detail/publication-ethics 


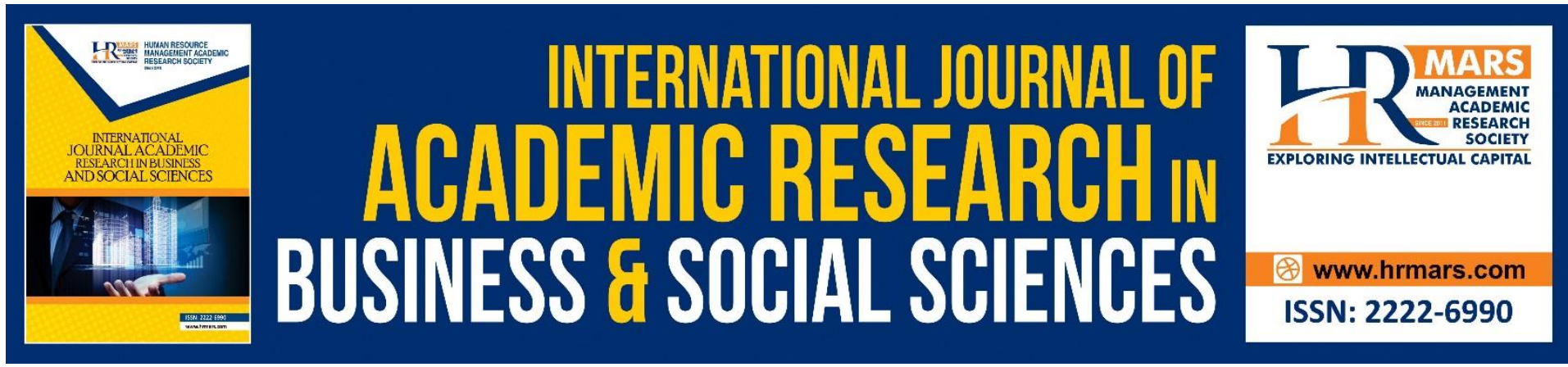

\title{
Teachers' Beliefs of Learner Autonomy in Secondary Schools
}

\author{
Siti Nur Yusof \\ Universiti Pendidikan Sultan Idris, Malaysia
}

\begin{abstract}
Learner autonomy is a key element in language learning that would enable the learners to act more effectively. The purpose of this study was to investigate Malaysian English language teachers' beliefs about learner autonomy in lower secondary schools. A total of 72 English language teachers answered the question items in a questionnaire. The collected data were analysed and interpreted in the form of percentage level for related items and questions. The results of the study showed that teachers are familiar with the concept of learner autonomy and believe that it has essential role in effective language learning.
\end{abstract}

Keywords: Leaner Autonomy, Teacher Beliefs, Independent Learning, Language Learning Beliefs, ESL

\section{Introduction}

Teachers should help their students realise and develop the skills which allow them to have control of their own learning and be able to use what they have learned outside the classroom, when the teacher is not present for help. However; language teachers' have been somehow ignored in these areas of research, and their attitudes and beliefs about learner autonomy is actually not known. There is a significant gap about the influence that teachers' beliefs have on how they teach and in particular, on whether and how they search for promoting learner autonomy. The purpose of this study was to investigate English language teachers' beliefs about learner autonomy.

\section{Learner Autonomy in Language Learning}

Learner autonomy in language education has been interpreted in various ways. 'Learner autonomy', 'learner independence', 'self direction', 'autonomous learning' and other similar terms have been used to refer to learner autonomy. Holec (1981) defines autonomy as accepting responsibility for one's own learning which includes planning for learning, being innovative in the learning process, and being able to evaluate that learning. This means possessing affective, motivational and metacognitive dimensions and presupposing a positive attitude to the purpose, content and process of learning and possessing well-developed metacognitive skills. Little (1991) defined autonomy as "a capacity-for detachment, critical reflection, decision-making, and independent action. It presupposes, but also entails, that the learner will develop a particular kind of psychological relation to the process and content of his learning" (p. 4). 
In traditional language teaching, teachers usually play a more significant role in the learning environment when compared to students. In this sense, teachers are the knowledge-givers who dominate the class from start to finish (Almusharraf, 2020). However, in order for learner autonomy to develop, the teacher's role must be shifted from teacher-focused to studentfocused instruction. The teacher must still be engaged, but her or his role changes when choosing appropriate methods to promote learner autonomy.

\section{Teachers' Beliefs on Learner Autonomy}

Teachers' beliefs can be defined as 'assumptions about all aspects of their work which teachers consider to be true or false' (Phipps \& Borg, 2009). Teachers' beliefs are beliefs that they have about education, teaching and learning which conduct their actions and behaviors as teachers. Teachers' perspectives and beliefs about learning and how it takes place can be affected by many factors like their cultural and educational background. With investigating and in necessary cases changing their beliefs we can improve and refine the process of learning and help learners become good language users and autonomous. These days the expanding demand to teach students to become autonomous learners has changed the ideas about teachers' and learners' role in language learning and teaching. The new perspectives concentrate on the activities that teachers can do to assist and simplify the students' learning (Yang, 1998). Teachers' beliefs have very great impact on their performance and therefore on the opportunities they give to their learners for learning. Knowing about these beliefs can influence teacher education and the way they are trained for becoming English language learners. Thus, understanding teachers' beliefs about autonomy is an essential part of designing activities with the purpose of developing learner autonomy.

\section{The Study}

The study aimed at identifying teachers' beliefs and reporting their practices with regard to the potential for learner autonomy among the students they teach. Hence, the study tried to find out how autonomy in learning is conceptualized and practised by the Malaysian ESL secondary school teachers with the following Research Questions (RQ) to be addressed:

1. What does 'learner autonomy' mean to Malaysian ESL secondary school teachers?

2. To what extent, according to the Malaysian ESL teachers, does learner autonomy assist L2 learning?

A survey was conducted as part of the researcher's pilot study and data were collected using a questionnaire that was adapted from Borg \& Al Busaidi (2012). The questionnaires were distributed to 100 secondary school teachers of English as a second language in a northern state of Malaysia. Only 72 questionnaires were returned. A descriptive statistical analysis was carried out using SPSS 23 to report on the results of the survey.

\section{Findings}

The results of the study are presented based on the research questions that the study is addressing. All respondents are teachers of English as a Second Language (ESL) from a northern state of Malaysia. These teachers are teaching English at the lower forms of secondary schools where the new curriculum is currently being used. 


\section{Defining Learner Autonomy}

The first research question attempts to investigate ESL teachers' understanding of the meaning of 'learner autonomy'. It was informed from the study that teachers have quite similar and different conceptions of learner autonomy. Table 1 shows the results for RQ1, that is: What does 'learner autonomy' mean to Malaysian ESL secondary school teachers?

Table 1: Results for RQ1

\begin{tabular}{|l|l|l|l|l|l|l|}
\hline Item & Statement & $\begin{array}{l}\text { Strongly } \\
\text { disagree }\end{array}$ & Disagree & Unsure & Agree & $\begin{array}{l}\text { Strongly } \\
\text { agree }\end{array}$ \\
\hline 4 & $\begin{array}{l}\text { Autonomy means that learners } \\
\text { can make choices about how } \\
\text { they learn }\end{array}$ & 2.8 & 2.8 & 9.7 & 59.7 & 25 \\
\hline 8 & $\begin{array}{l}\text { Learner autonomy means } \\
\text { learning without a teacher }\end{array}$ & 2.8 & 37.5 & 19.4 & 37.5 & 2.8 \\
\hline 13 & $\begin{array}{l}\text { Learner autonomy can be } \\
\text { achieved by learners of all } \\
\text { cultural backgrounds. }\end{array}$ & 0 & 4.2 & 8.3 & 63.9 & 23.6 \\
\hline 17 & $\begin{array}{l}\text { Learner autonomy is a rejection } \\
\text { of traditional teacher-centered } \\
\text { teaching }\end{array}$ & 4.2 & 26.1 & 15.3 & 37.5 & 6.9 \\
\hline 20 & $\begin{array}{l}\text { Learner autonomy is only } \\
\text { possible with adult learners. }\end{array}$ & 12.5 & 55.6 & 13.9 & 18.1 & 0 \\
\hline 23 & $\begin{array}{l}\text { Learner autonomy requires the } \\
\text { learner to be independent of } \\
\text { theteacher's guide. }\end{array}$ & 1.4 & 43.1 & 13.9 & 36.1 & 5.6 \\
\hline 24 & $\begin{array}{l}\text { Learner autonomy is a concept } \\
\text { which is not suitable to } \\
\text { Malaysian learners. }\end{array}$ & 15.3 & 47.2 & 20.8 & 15.3 & 1.4 \\
\hline 32 & $\begin{array}{l}\text { The ability to monitor one's } \\
\text { learning is central to learner } \\
\text { autonomy. }\end{array}$ & 0 & 0 & 5.6 & 79.2 & 15.3 \\
\hline 37 & $\begin{array}{l}\text { To become autonomous, } \\
\text { learners need to develop the } \\
\text { ability to evaluate their own } \\
\text { learning. }\end{array}$ & 0 & 2.8 & 9.7 & 69.4 & 18.1 \\
\hline
\end{tabular}

The results indicated a total of 84.7 percent of the teachers agree (59.7 percent) and strongly agree ( 25 percent) that autonomy refers to the learner's ability in making choices about how they learn. Meanwhile, teachers who believe that learner autonomy means learning without a teacher were divided as both agree and disagree at 40.3 percent with 19.4 percent unsure. However, 44.5 percent of the respondents disagree that learner autonomy requires the students to be independent of the teacher. This indicated that in asserting learner autonomy, teachers still have a role to play in the teaching of English. In terms of the classroom approach, teachers who are either agreeing (44.4 percent) or disagreeing (30.3 percent) to the idea that learner autonomy ignores a traditional teacher-centered classroom while 15.3 percent are unsure. Quite a number of respondents have doubts (20.8 percent) as to whether or not learner autonomy is suitable for the local learners, but more than half of the respondents 
(62.5 percent) disagree with a notion that learner autonomy is not suitable for local learners of ESL. Results also indicated 87.5 percent agree that learner autonomy could be achieved by learners of all cultural backgrounds. Most of the teachers believe that students ability to monitor their learning is important in developing learner autonomy in which 94.5 percent of respondents agree to this notion with 87.5 percent suggested that students have to develop their ability to evaluate their own learning in order to be autonomous. Generally, from the survey results, it could be concluded that teachers have their own interpretations of what learner autonomy means in which majority proposed that learner autonomy occurs at all ages and cultural background that see learners as being able to decide, monitor and evaluate their own learning with or without the help from their teachers.

\section{Learner autonomy and second language learning}

This section will address Research Question 2 that is: to what extent, according to the Malaysian ESL teachers, does learner autonomy assist L2 learning? In answering this question, several items from Section 1 of the questionnaire are grouped and presented in Table 2. From the survey, it was identified that a majority (73.3 percent) of the ESL secondary school teachers agrees that learner autonomy is possible to instill among both young language learners and adult learners and more than half or these teachers (86.1 percent) do not believe that it is harder to promote learner autonomy with proficient language learners as opposed to the beginners. However, a total of 51.4 percent agree that lack of autonomy is likely to contribute to students becoming ineffective language learners. A total 93 percent of the teachers agree that learner autonomy has a positive effect on success as a language learner where the teachers (87.5 percent) indicated that through learner autonomy, language learners tend to learn the target language more effectively. It is also indicated (89.9 percent) that confident language learners are more likely to develop autonomy in the learning of the English language. From the results, it could be concluded that ESL teachers feel autonomy do assist ESL students in becoming effective English language learners and autonomy is possible to be promoted to young and adult language learners. However, in any case, confident language learners would develop more autonomy in their learning. 
Table 2: Results of RQ2

\begin{tabular}{|l|l|l|l|l|l|l|}
\hline Item & Statement & $\begin{array}{l}\text { Strongly } \\
\text { disagree }\end{array}$ & Disagree & Unsure & Agree & $\begin{array}{l}\text { Strongly } \\
\text { agree }\end{array}$ \\
\hline 1 & $\begin{array}{l}\text { Language learners of all ages } \\
\text { can develop learner } \\
\text { autonomy }\end{array}$ & 0 & 11.3 & 15.5 & 60.6 & 12.7 \\
\hline 5 & $\begin{array}{l}\text { Individuals who lack } \\
\text { autonomy are likely to be } \\
\text { ineffective language } \\
\text { learners. }\end{array}$ & $\begin{array}{l}\text { It is harder to promote } \\
\text { learner autonomy with } \\
\text { proficient language learners } \\
\text { than with weak language } \\
\text { learners. }\end{array}$ & 25 & 23.6 & 38.9 & 12.5 \\
\hline 10 & $\begin{array}{l}\text { It is possible to promote } \\
\text { learner autonomy with both } \\
\text { young language learners } \\
\text { and with adults. }\end{array}$ & 0 & 52.1 & 15.5 & 19.7 & 11.3 \\
\hline 11 & $\begin{array}{l}\text { Confident language learners } \\
\text { are more likely to develop } \\
\text { autonomy than those who } \\
\text { lack confidence. }\end{array}$ & 0 & 2.8 & 5.6 & 65.3 & 26.4 \\
\hline 12 & $\begin{array}{l}\text { Learner autonomy allows } \\
\text { language learners to learn } \\
\text { more effectively. } \\
\text { Learner autonomy has a } \\
\text { positive effect on success as } \\
\text { a language learner. }\end{array}$ & 0 & 2.8 & 9.7 & 72.2 & 15.3 \\
\hline 36 & 0.8 & 72.2 & 20.8 \\
\hline
\end{tabular}

\section{Conclusion}

The study provides an insight on how English language teachers view learner autonomy at the lower secondary school level. There is a need for teachers to develop learner autonomy that will undoubtedly benefit in the long run. Learner autonomy is an interesting area of study, both in theory as well as in practice, Keeping in view the individual pace, style, context and manner of learning, learner autonomy is highly advisable to be induced in the classroom. Modern teaching/learning gadgets are highly supportive of learner autonomy at every step. According to teachers, learner autonomy has considerable effect on language learning and autonomous learners are more effective learners. They stated that teachers should help and support their learners to promote autonomy and become autonomous learners. Autonomous learning is the outcome of a long process and training. As such, teachers should be aware of the benefits of promoting learner autonomy and in the long run should know how to deal with any challenges that could hinder the development of learner autonomy (Almusharraf, 2020).

The findings of this study are in line with the findings of previous studies such as Borg \& AlBusaidi (2012) and Balçıkanlı (2010) which found that teachers are aware of the concept of 
learner autonomy and are likely to promote it for more effective learning.

\section{Acknowledgement}

Thank you to all the lower secondary English language teachers who took part in the study and EPRD for allowing the researcher to conduct the study.

\section{Corresponding Author}

Siti Nur Yusof

PhD TESOL candidate at Universiti Pendidikan Sultan Idris, Malaysia. She has been teaching English for 13 years. She can be reached

Email: yusof.sitinur@gmail.com

\section{References}

Almusharraf, N. (2020) Teachers' perspectives on promoting learner autonomy for vocabulary development: A case study, Cogent Education, 7 (1), DOI: $10.1080 / 2331186 X .2020 .1823154$

Balçıkanlı, C. (2010). Learner Autonomy inLanguage Learning: Student Teachers' Beliefs. Australian Journal of Teacher Education, 35(8), 90-103.

Borg, S., \& Al-Busaidi, S. (2012). Learner Autonomy: English Language Teachers' Beliefs and Practices. ELT Research Paper, 12-07. London: British Council.

Dam, L., Eriksson, R., Little, D., Miliander, J., \& Trebbi, T. (1990). Towards a definition of autonomy. In T. Trebbi (Ed.), Third Nordic workshop on developing autonomous learning in the FL classroom (pp. 102-103). Bergen: University of Bergen.

Holec, H. (1981). Autonomy and foreign language learning. Oxford: Pergamon Press.

Little, D. (1991). Learner autonomy: Definitions, issues and problems. Authentic Language Learning Resources Ltd.

Najeeb, Sabitha. S. R. (2013). Learner autonomy in language learning. Procedia- Social and Behavioral Sciences 70, 1238 -

Phipps, S., \& Borg, S. (2009). Exploring tensions between teachers' grammar teaching beliefs and practices. System, 37(3), 380-390.

Tütünis, B. (2011). Changing Teacher Beliefs and Attitudes towards Autonomous Learning. In D. Gardner, Fostering Autonomy in Language Learning. Gaziantep: Zirve University, 161165.

Yang, N. D. (1998).Exploring a new role for teacher: promoting learner autonomy. System, 26, 127-135. 